\title{
First report of nt230(del4) mutation in the MDR1 gene in German Shepherds in Southern Brazil
}

\author{
Ananda da Rocha Pires ${ }^{*}$ (iD) Daniel Gerardi' ${ }^{2}$ (D) Tainor de Mesquita Tisotti ${ }^{1}$ (i) \\ Priscila Beatriz da Silva Serpa ${ }^{3}$ (D) Cláudio Corrêa Natalini ${ }^{4}$ iD
}

${ }^{1}$ Department of Clinical Studies, Ontario Veterinary College, University of Guelph, Guelph, ON, N1G 2W1, Canada. E-mail: apires@uoguelph.ca..'Corresponding author.

${ }^{2}$ Departamento de Medicina Animal, Universidade Federal do Rio Grande do Sul (UFRGS), Porto Alegre, RS, Brasil.

${ }^{3}$ Department of Comparative Pathobiology College of Veterinary Medicine, Purdue University, West Lafayette, IN, United States of America. ${ }^{4}$ Clinical Sciences, Mississipi State University, Starkville, MS, United States of America.

\begin{abstract}
The P-glycoprotein (P-gp) is a transmembrane protein encoded by the MDR1 gene that functions as a biological barrier by extruding toxins and xenobiotics out of cells. The MDR1 gene can carry a mutation called nt230(del4), which is a deletion of four base pairs resulting in the formation of a non-functional protein that may predispose to severe toxicosis, as observed in dogs with sensitivity to ivermectin. Several breeds have been described as carriers of the mutation, including German Shepherds (GS). However, the presence of the mutant allele in this breed has not been described in Brazil. This study aimed to determine the genotypic and allelic frequency of the nt230(del4) mutation in the MDR1 gene in GS from Southern Brazil. Blood samples were collected from 79 GS in the state of Rio Grande do Sul and genotype for the MDR1 gene was performed. Seventy-eight (98.7\%) dogs were dominant homozygous genotype (wild) and one (1.3\%) was heterozygous. This study showed that there is a low frequency (0.6\%) of the mutant allele while the frequency of the wild allele is high (99.4\%) in this specific population. This is the first report of the presence of the nt230(del4) mutation in the MDR1 gene in GS in Brazil. This information is important for breeders to prevent dissemination of the mutant allele in the national breeding population and international exchange of animals for breeding; for owners and veterinarians to be aware when dispensing and administering medications for GS dogs in Brazil. Key words: $A B C B 1$, canine, P-glycoprotein.
\end{abstract}

\section{Primeiro relato da mutação nt230(del4) no gene MDR1 em Pastores} Alemães no Sul do Brasil

RESUMO: A Glicoproteina-P é uma proteina transmembrana codificada pelo gene MDR1 que atua como uma barreira fisiológica através da extrusão de toxinas e xenobióticos para fora das células. O gene MDR1 pode carregar uma mutação chamada nt230(del4) que é uma deleção de quatro pares de bases, resultando na formação de uma proteína não-funcional que pode predispor à toxicoses graves, como as observadas em cães sensiveis à ivermectina. Diversas raças de cães foram descritas como portadoras da mutação nt230(del4), incluindo Pastores Alemães (PA). Entretanto, a presença do alelo mutante nessa raça não foi descrita em cães no Brasil. O objetivo desse estudo foi determinar a frequência genotípica e alélica da mutação nt230(del4) em PA no sul do Brasil. Amostras de sangue foram coletadas de 79 PA no estado do Rio Grande do Sul e o genótipo dos cães para o gene MDR1 realizado. Setenta e oito (98.7\%) cães foram homozigotos dominantes (selvagem) e um (1.3\%) tinha genótipo heterozigoto. A frequência do alelo mutante foi baixa (0.6\%), enquanto a frequência do alelo selvagem foi alta (99.4\%) nesta população. Este é o primeiro relato da presença desta mutação nt230(del4) no gene MDR1 em PA no Brasil. Esta informação é importante para criadores a fim de prevenir a disseminação do alelo mutante na população de criadores da raça no Brasil e programas internacionais de troca de animais para criação, para tutores e veterinários estarem conscientes quando prescreverem e administrarem medicações para cães PA no Brasil.

Palavras-chave: $A B C B 1$, canino, Glicoproteina- $P$.

\section{INTRODUCTION}

The MDR1 (ABCB1-1) is a 28-exon gene localized on chromosome 14 in the Canis familiaris species. This gene encodes a transmembrane protein called P-glycoprotein (P-gp), that acts as an efflux pump for a range of substances in the body such as chemotherapy drugs, immunosuppressants, antiparasitic drugs, antimicrobial agents, drugs acting on the cardiovascular system, opioids and steroids hormones (GRAMER et al., 2011; GEYER \& JANKO, 2012; MEALEY, 2013).

The P-gp is distributed in different body tissues, such as blood-brain barrier, testes, placenta, 
liver, kidneys, and intestines, limiting the absorption of drugs and promoting elimination through bile and urine (GRAMER et al., 2011). In the blood-brain barrier, P-gp restricts substances from entering the central nervous system, establishing an important defense mechanism in preventing neurotoxicity (SCHINKEL \& JONKER, 2003).

The mutation nt230(del4) on the MDR1 gene in dogs is a four-base pair depletion on the fourth exon of the MDR1 gene, generating a premature stop codon, creating a non-functional glycoprotein less than $10 \%$ of its original sequence of amino acids (MEALEY et al., 2001; FECHT et al., 2007). For dogs, three different genotypes for the $M D R 1$ gene are described: MDRl intact dogs $(M D R 1+/+)$ is the animal that does not have the mutation; heterozygous (MDR1 +/-) is the carrier of one mutant allele; and homozygous mutant (MDRI $-/-)$ is the one that manifests the mutation (MEALEY \& MEURS, 2008). Dogs that are homozygous or heterozygous have a higher predisposition to intoxication by P-gp substrates than homozygous wild-type dogs. Ivermectin intoxication is the most important toxicosis related to nonfunctional P-gp in dogs, since it allows ivermectin to cross the bloodbrain barrier and cause neurologic signs and possible death (GEYER \& JANKO, 2012).

Studies have shown the presence of the mutant allele in different breeds of dogs in several countries with Collies being the most commonly affected breed (MEALEY et al., 2001; HUGNET et al., 2004; NEFF et al., 2004; GEYER et al., 2005; MEALEY et al., 2005; FETCH et al., 2007; GEYER et al., 2007; MEALEY \& MEURS, 2008; GRAMER et al., 2011; MIZUKAMI et al., 2011; TAPPIN et al., 2012; MEALEY, 2013). In Brazil, German Shepherd (GS) dogs are commonly used not only as pets but also as working dogs, having an important role in our society. The nt230(del4) mutation has been described in GS dogs and there is a discrepancy between studies about the origin of this mutation as well as the frequency in this breed. Based on this information and on the limited data about the frequency of the mutant allele in GS in Brazil, the objective of this study was to determine if the MDR1-230(del4) mutation is present and what is the frequency of genotypes and mutant allele in GS dogs in Brazil.

\section{MATERIALS AND METHODS}

Blood samples were collected from 79 GS dogs deemed healthy, based on history and physical examination, from the jugular or cephalic veins, using EDTA vacuum tubes. The samples were kept refrigerated at $4{ }^{\circ} \mathrm{C}$ for further DNA analyses.

The animals were obtained from the Brazilian Army, Brazilian Air Force, State Military Police, and private kennels, client owned dogs, and patients from the Federal University of Rio Grande do Sul Veterinary Teaching Hospital. The samples were collected in different cities of the state of Rio Grande do Sul (Table 1). Seventy-nine dogs had a validated Brazilian Confederation of Kennel Clubs (CBKC) pedigree presented, confirming their pure-breed status.

\section{DNA analysis}

DNA was extracted from whole blood using a commercial kit. The DNA analysis was performed as previously described (FECHT et al., 2007). DNA amplification was carried in a total volume of $24 \mu \mathrm{L}$, containing approximatelly $200 \mathrm{ng}$ DNA, , buffer $1 \mathrm{x}$ (20mM Tris- $\mathrm{HCl} \mathrm{pH} 8.4,50 \mathrm{mM} \mathrm{KCl}), 1.5 \mathrm{mM} \mathrm{MgCl}$, $2.5 \%$ DMSO, $0.4 \mathrm{mM}$ dNTP, $0.5 \mu \mathrm{M}$ of each primer (forward 5'- GGC TTG ATA GGT TGT ATA TGT TGG TG- 3' and reverse 5'- ATT ATA ACT GGAAAA GTT TTG TTT- 3'), and 1 U of Taq DNA Polymerase. The PCR amplification protocol was the following: protocol: initial denaturation cycle at $94{ }^{\circ} \mathrm{C}$ during 4 minutes, followed by 32 consecutive denaturation cycles at $94{ }^{\circ} \mathrm{C}$ for 30 seconds each, annealing at 55 ${ }^{\circ} \mathrm{C}$ for 1 minute, and extension at $72{ }^{\circ} \mathrm{C}$ for 30 seconds.

For genotyping, electrophoresis was performed in $6 \%$ denaturing polyacrylamide gel and visualized with silver nitrate stain (SANGUINETTI et al., 1994). The samples were denatured at $95{ }^{\circ} \mathrm{C}$ for 5 minutes.

\section{RESULTS AND DISCUSSION}

The average age of the animals in the study was 5 years old $( \pm 4.5)$. From all animals, 43

Table 1 - Number of animals from each city in Rio Grande do Sul where blood samples were collected.

\begin{tabular}{lc}
\hline City & Number of animals \\
\hline Porto Alegre & 47 \\
Canoas & 8 \\
\hline Viamão & 3 \\
Gravataí & 9 \\
\hline Novo Hamburgo & 2 \\
\hline Torres & 10 \\
\hline
\end{tabular}


were females $(54.4 \%)$ and 36 were males $(45.6 \%)$. Out of the 79 dogs who presented pedigree at the time of blood sampling, 10 were originated from different Brazilian states, or had at least one parent from another country (Table 2). All 79 GS were brown-colored.

Genotype evaluation showed that 78 (98.7\%) dogs had MDR1 +/+ genotype. One dog $(1.3 \%)$ had MDR $1+/$-genotype. The frequency of the mutant allele found on 79 GS dogs in this study was $0,6 \%$. This study is the first to show the presence of the mutant allele for the nt230(del4) mutation in the MDR1 gene in GS dogs in Brazil.

Among the studies evaluating the presence of MDRl gene mutation in GS dogs (MEALEY \& MEURS, 2008; BARBET et al., 2009; ERKENS et al., 2009; GRAMER et al., 2011; TAPPIN et al., 2012; ASAWAKARN et al., 2012; DEKEL et al., 2017; MONOBE et al., 2015) to date, only one was able to show the presence of the mutation in this breed (MEALEY \& MEURS, 2008). Mealey and Meurs (2008) have detected a mutant allele frequency of $6 \%$ in $166 \mathrm{GS}$ dogs. In that population, 149 dogs were MDR1 +/+ (90\%), 14 MDR1 +/- (8\%), and 3 MDR1 -/- (2\%) (MEALEY \& MEURS, 2008). In the present study, we observed a lower frequency of the mutant allele in GS dogs than previously found by MEALEY $\&$ MEURS (2008).

The frequency of the mutant allele in GS dogs is considerably lower than observed in other breeds, as shown by previous studies (MEALEY \& MEURS, 2008; GRAMER et al., 2011). This is most likely due to the fact that this breed does not share direct ancestry with Collie dogs (GRAMER et

Table 2 - Geographic distribution of 79 German Shepherd dogs based on their genetic origin.

\begin{tabular}{|c|c|}
\hline Brazilian states & Number of animals \\
\hline Rio de Janeiro & 1 \\
\hline Rio Grande do Sul & 69 \\
\hline Santa Catarina & 2 \\
\hline São Paulo & 2 \\
\hline \multicolumn{2}{|c|}{ 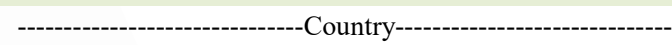 } \\
\hline Argentina & 1 \\
\hline China & 1 \\
\hline France & 1 \\
\hline Germany & 1 \\
\hline Italy & 1 \\
\hline
\end{tabular}

al., 2011). In the history of the breed development, GS are related to the White Swiss Shepherds (WSS) (GRAMER et al., 2011), which possess a mutant allele frequency between 10 and 14\% (GEYER et al., 2007). An analysis of haplotypes performed in WSS dogs has shown that the nt230(del4) mutation in the MDRl gene in this breed is closely related to the one found in Collies, sharing three out of the four haplotypes found on the Collie's mutation (GEYER et al., 2007). However, as the most significant similarity between these haplotypes occurs among WSS and sighthounds, it is possible that German Shepherds inherited the mutation from the sighthound lineage (GEYER et al., 2007). In one study, in three described homozygous dogs for the MDR1-nt230(del4) mutation, two were WSS and one was a descendent from white shepherd dogs (white-factored dog). The literature is not concise in relation to the ancestry connections between GS and WSS (MEALEY \& MEURS, 2008; GRAMER et al., 2011), and, to date, it is unknown if the MDR1-nt230(del4) mutation is related to an allele for the white color coat (MEALEY \& MEURS, 2008).

According to the CBKC, in 2019, 4,609 GS dogs had a pedigree registration completed, and 31 GS were imported from other countries for breeding purposes (CBKC, 2019). Based on this information, it is possible that the mutation found in Brazil was introduced by imported GS. To date, only one study has investigated the presence of the MDR Int230(del4) mutation in GS in Brazil (MONOBE et al., 2015). MONOBE et al. (2015) did not find the the mutant allele in 55 tested brown-colored GS. Nonetheless, they showed through the maximum mutant prevalence (MMP) equation, which considers the number of tested dogs and the total number of dogs in the population of each breed, that in Brazil, GS dogs have an MMP of 5.2\%, different from what has been previously reported in the studies from US (MEALEY \& MEURS, 2008).

One of the limitations of this study was the lack of complete data about the kinship of the dogs, particularly from different origins. However, the dog identified as a heterozygous genotype had a sibling with a wild-type homozygous genotype. These two dogs were registered at the German Shepherd Brazilian Club (Clube Brasileiro do Pastor AlemãoCBPA) as a brown-coloured purebred German Shepherd as well as their ancestors. Furthermore, as the frequency of mutant allele was low, the number of included dogs in our study may not have been enough to detect the real prevalence of the mutant allele in GP in Brazil. 


\section{CONCLUSION}

The present work has shown for the first time the presence of the mutant allele of the nt230(del4) mutation on the MDRl gene in German Shepherds in Brazil. Even with the low frequency of the mutant allele found in this study, owners, trainers, caretakers, and veterinarians should be aware of this when choosing treatments or breeding these dogs, in order to avoid intoxications or transferring the mutant allele to the next generations. However, future studies with a large number of dogs are necessary to demonstrate the actual frequency of the MDR1-nt230(del4) mutation in the German Shepherds in Brazil.

\section{ACKNOWLEDGEMENTS}

To the Conselho Nacional de Desenvolvimento Científico e Tecnológico (CNPq), and Coordenação de Aperfeiçoamento de Pessoal de Nível Superior (CAPES) for the financial support. We also would like to thank Dr. Iraci Torres and Dr. Rosane Gomez from the Department of Pharmacology of the Universidade Federal do Rio Grande do Sul for the technical support and all German Shepherd dog owners, trainers, and breeders who contributed to the study.

\section{BIOETHICS AND COMMITTEE APPROVAL \\ BIOSECURITY}

This study was approved by the Animal Use Ethics Committee protocol of the Universidade Federal do Rio Grande do Sul by the number 33298 and written consent was given by the owners, trainers and veterinarians for the participation in the study.

\section{DECLARATION OF CONFLICT OF INTEREST}

The authors declare no conflict of interest.

\section{AUTHORS' CONTRIBUTIONS}

All authors contributed equally for the conception and writing of the manuscript. All authors critically revised the manuscript and approved of the final version.

\section{REFERENCES}

ASAWAKARN, S., et al. Determination of multidrug resistance (MDR1) gene and its mutations in dogs by using polymerase chain reaction. Thai Journal of Veterinary Medicine, v.42, n.1, p.3742, 2012. Available from: <https://he01.tci-thaijo.org/index.php/ tjvm/article/view/9829 > . Accessed: Jul. 11, 2020.

BARBET, J.L., et al. ABCB1-1 Delta (MDR1-1 Delta) genotype is associated with adverse reactions in dogs treated with milbemycin oxime for generalized demodicosis. Veterinary Dermatology, v.20, p.111-114, 2009. Available from: <https://onlinelibrary.wiley. com/doi/abs/10.1111/j.1365-3164.2008.00725.x>. Accessed: Jul. 11, 2020. doi: 10.1111/j.1365-3164.2008.00725.x.

CBKC, Confederação Brasileira de Cinofilia. Relatório anual de atividades cinófilas. Online report. Rio de Janeiro. p. 8, 41, 2019. Available from: <https://cbkc.org/cbkc/estatisticas/2019>. Accessed: Jul. 20, 2020.

DEKEL, Y., et al. Frequency of canine nt230(del4) MDR1 mutation in prone pure breeds, their crosses and mongrels in Israel - insights from a worldwide comparative perspective. BMC Veterinary Research, v.13, p.333. 2017. Available from: <https:// www.ncbi.nlm.nih.gov/pmc/articles/PMC5683241/>. Accessed: Jul. 11, 2020. doi: 10.1186/s12917-017-1251-9.

ERKENS, T, et al. Presence of the ABCB1 (MDR1) deletion mutation causing ivermectin hypersensitivity in certain dog breeds in Belgium. Vlaams Diergeneeskundig Tijdschrift, v.78, n.4, p.256-260, 2009. Available from: <https://vdt.ugent.be/sites/ default/files/art78404.pdf >. Accessed: Jul. 11, 2020.

FECHT, S, et al. Analysis of the canine MDR1-1Delta mutation in the dog breed Elo. Journal of Veterinary Medicine, Series A: Physiology, Pathology, Clinincal Medicine, v.54, p.401-405, 2007. Available from: $<$ https://onlinelibrary.wiley.com/doi/abs/1 0.1111/j.1439-0442.2007.00966.x>. Accessed: Jul. 11, 2020. doi: 10.1111/j.1439-0442.2007.00966.x.

GEYER, J., et al. Frequency of the nt230 (del4) MDR1 mutation in Collies and related dog breeds in Germany. Journal of Veterinary Pharmacology and Therapeutics v.28, p.545-551, 2005. Available from: $<$ https://onlinelibrary.wiley.com/doi/abs/1 0.1111/j.1365-2885.2005.00692.x>. Accessed: Jul. 18, 2020. doi: 10.1111/j.1365-2885.2005.00692.x.

GEYER, J., JANKO, C. Treatment of MDR1 mutant dogs with macrocyclic lactones. Current Pharmaceutical Biotechnology, v.13, p.969-986. 2012. Available from: <https://www.ncbi. nlm.nih.gov/pmc/articles/PMC3419875/pdf/CPB-13-969.pdf>. Accessed: Jul. 18, 2020. doi: 10.2174/138920112800399301.

GEYER, J., et al. Detection of the nt230(del4) MDR1 mutation in White Swiss Shepherd dogs: case reports of doramectin toxicosis, breed predisposition, and microsatellite analysis. Journal of Veterinary Pharmacology and Therapeutics, v.30, p.482-485, 2007. Available from: <https://onlinelibrary.wiley.com/doi/ abs/10.1111/j.1365-2885.2007.00885.x. . . Accessed: Jul. 19, 2020. doi: $10.1111 /$ j.1365-2885.2007.00885.x.

GRAMER, I., et al. Breed distribution of the nt230(de14) MDR1 mutation in dogs. Veterinary Journal, v.189, p.67-71, 2011. Available from: <https://www.sciencedirect.com/science/article/ abs/pii/S1090023310002261?via\%3Dihub>. Accessed: Jul. 11, 2020. doi: 10.1016/j.tvj1.2010.06.012.

HUGNET, C., et al. Frequency of the mutant MDR1 allele associated with multidrug sensitivity in a sample of Collies from France. Journal of Veterinary Pharmacology and Therapeutics, v.27, p.227-229. 2004. Available from: <https://doi.org/10.11 11/j.1365-2885.2004.00585.x>. Accessed: Jul. 20, 2020. doi: 10.1111/j.1365-2885.2004.00585.x.

MEALEY, K.L., et al. Ivermectin sensitivity in collies is associated with a deletion mutation of the MDR1 gene. Pharmacogenetics, v.11, p.727-733, 2001. Available from: < https://journals.lww.com/ 
jpharmacogenetics/Abstract/2001/11000/Ivermectin_sensitivity in_collies_is_associated.12.aspx>. Accessed: Jul. 18, 2020. doi: $10.1097 / 00008571-200111000-00012$.

MEALEY, K.L., et al. Frequency of the mutant MDR1 allele associated with multidrug sensitivity in a sample of herding breed dogs living in Australia. Veterinary Parasitology, 131, 193-196, 2005. Available from: <https://doi.org/10.1016/j. vetpar.2005.05.004>. Accessed: Jul. 11, 2020. doi: 10.1016/j. vetpar.2005.05.004.

MEALEY, K.L., MEURS, K.M. Breed distribution of the ABCB11D (multidrug sensitivity) polymorphism among dogs undergoing ABCB1 genotyping. Journal of American Veteterinary Medical Association, v.233, p. 921-924, 2008. Available from: <https:// doi.org/10.2460/javma.233.6.921>. Accessed: Jul. 20, 2020. doi:10.2460/javma.233.6.921.

MEALEY, K. L. Adverse drug reactions in veterinary patients associated with drug transporters. Veterinary Clinic of North Americal Small Animal Practioners, v.43, p.1067-1078, 2013. Available from: <https://doi.org/10.1016/j.cvsm.2013.04.004>. Accessed: Jul. 11, 2020. doi: 10.1016/j.cvsm.2013.04.004.

MONOBE, M.M., et al. Frequency of the MDR1 mutant allele associated with multidrug sensitivity in dogs from Brazil. Veterinary Medicine: Research and Reports, v. 6, p. 111-117,
2015. Available from: <https://www.ncbi.nlm.nih.gov/pmc/ articles/PMC6067530/pdf/vmrr-6-111.pdf>. Accessed: Jul. 20, 2020. doi: 10.2147/VMRR.S72373.

NEFF, M.W., et al. Breed distribution and history of canine MDR1-1 $\Delta$, a pharmacogenetic mutation that marks the emergence of breeds from the collie lineage. Proceedings of the National Academy of Sciences of the United States of America, v.101, n.32, p.11725-11730, 2004. Available from: <https://doi. org/10.1073/pnas.0402374101>. Accessed: Jul. 20, 2020. doi: 10.1073/pnas.0402374101.

SANGUINETTI, C.J., et al. Rapid silver staining and recovery of PCR products separated on polyacrylamide gels. Biotechniques, v.17, p.914-921, 1994. Available from: < https://pubmed.ncbi.nlm. nih.gov/7840973/>. Accessed: Jul. 18, 2020.

SCHINKEL, A.H., JONKER, J.W. Mammalian drug efflux transporters of the ATP binding cassette (ABC) family: an overview. Advanced Drug Delivery Reviews, v.55, n.1, p.3-29, 2003. Available from: < https://doi.org/10.1016/S0169-409X(02)00169-2>. Accessed: Jul. 20, 2020. doi: 10.1016/s0169-409x(02)00169-2.

TAPPIN, S.W., et al. Frequency of the mutant MDR1 allele in dogs in the UK. Veterinary Record. 171, 72, 2012. Available from: $<$ http://dx.doi.org/10.1136/vr.100633>. Accessed: Jul. 20, 2020. doi: $10.1136 /$ vr. 100633 . 